\title{
Vitka organizacija v javnem sektorju
}

\author{
Emil Trontelj \\ Upravna enota Slovenska Bistrica; Slovenija \\ emil.trontelj@gmail.com
}

\section{IZVLEČEK}

\begin{abstract}
Javni sektor $v$ sodobnih družbah pomembno vpliva na vsa področja človekovega organiziranega delovanja, s tem pa tudi na celoten gospodarski, socialni, kulturni in splošni civilizacijski razvoj družbe. Spremembe okolja ter vedno višja pričakovanja strank kot uporabnikov javnih storitev zahtevajo od subjektov javnega sektorja izboljšanje procesov delovanja zaradi zmanjšanja stroškov, krajšanja časa izvajanja storitev ter boljše kakovosti opravljenih storitev. Politične oblasti so predvsem v Veliki Britaniji, Združenih državah Amerike in na Švedskem spodbujale subjekte javnega sektorja, naj za povečanje učinkovitosti uvedejo v svoje delovanje prakse zasebnega sektorja, med drugim tudi koncept vitke proizvodnje, ki ima izhodišče $v$ Toyotinem proizvodnem sistemu. Izkušnje so večinoma zelo pozitivne, saj se je čas trajanja postopkov oziroma izvajanja storitev bistveno skrajšal, povečala se je produktivnostzaposlenih, izboljšalo pa se je tudi zadovoljstvo uporabnikov storitev. Zaradi določenih posebnosti je uvedba vitke organizacije v javni sektor precej zahtevnejša kot v subjektih realnega sektorja.
\end{abstract}

Ključne besede: javni sektor, vitka organizacija, javna uprava, vitka proizvodnja

$J E L: Z 00$

\section{Uvod}

Država kot temeljna in osrednja socialna tvorba potrebuje za svoje delovanje institucije oziroma službe, ki delujejo na posameznih področjih družbenega življenja.Spremembe okolja tervedno višja pričakovanja strankkotuporabnikov javnih storitev zahtevajo od subjektov javnega sektorja izboljšanje procesov delovanja zaradi zmanjšanja stroškov, krajšanja časa izvajanja storitev ter boljše kakovosti opravljenih storitev. Pritisk davkoplačevalcev na zmanjševanje stroškov delovanja javnega sektorja je stalen in izrazit, zato politične oblasti z namenom povečanja učinkovitosti javnega sektorja v njegovo delovanje prenašajo prakse zasebnega sektorja, kot so upravljanje sprememb, procesni vidik poslovanja, strateški modeli upravljanja ipd. Tako so izvršilne oblasti v nekaterih državah kot eno izmed možnih sistemskih orodij izboljšav že uvajale metode in tehnike vitke proizvodnje oziroma vitke organizacije v delovanje institucij javnega sektorja. 
Namen prispevka je predvsem prikazati rezultate uvajanja vitke organizacije v javni sektor v določenih državah in pri tem izpostaviti vse specifike tovrstne uvedbe. Želimo priti do celovitih ugotovitev, ali so metode in tehnike vitke organizacije uporabne za izboljšanje učinkovitosti delovanja javnega sektorja ter kako bi vitko organizacijo bilo mogoče uvesti tudi v subjektih javnega sektorja Republike Slovenije.

Pri raziskovanju bomo uporabili metodo kompilacije, s katero bomo zbrali nekaj dognanj avtorjev s širšega področja vitke organizacije in opredelitev osnovnih pojmov s pomočjo strokovne literature, ter metodo študija primerov kot eno od oblik kvalitativnih raziskovalnih pristopov.

\section{Vitka organizacija}

Vitka organizacija (angl. Lean Organisation) je strateška usmeritev, ki celovito in sistematično prepoznava in odstranjuje potrate iz procesa poslovanja. Cilj njene uporabe je iz delovanja odstraniti vse, kar z vidika kupca ne prinaša dodane vrednosti proizvodu ali storitvi (angl. non-value-added activities). Zato njena uporaba lahko pomembno skrajša čas od prejema naročila kupca do dostave končnega izdelka.

Pojma vitka organizacija ter vitka proizvodnja sta vsebinsko sicer zelo identična. Praktično vsak avtor ima svoj lastni pristop in tisti, ki govorijo o vitkosti v proizvodnih procesih, praviloma uporabljajo termin »vitka proizvodnja», avtorji, ki pa preučujejo načela vitkosti v storitvenih dejavnostih in pisarniškem poslovanju, pa največkrat koristijo izraz »vitka organizacija«.

Malayeff (2007) opredeljuje vitko organizacijo kot menedžerski pristop, ki si prizadeva maksimirati vrednost za stranke, tako notranje in zunanje, s hkratnim odpravljanjem nepotrebnih aktivnosti in opravil.

Bhatia in Drew (2006) opredeljujeta vitko proizvodnjo kot skupek metod in tehnik, s katerimi se izboljšuje produktivnost skozi bolj strukturirano reševanje problemov v skupinah, ustreznejšo razporeditev resursov in bolj prefinjen pristop k upravljanju znanja.

Vitka proizvodnja je tako koncept oziroma filozofija, usmerjena v izločanje potrat iz delovnega procesa in maksimiranje toka vrednosti. $V$ delu Lean Thinking sta Womack in Jones (1996) ugotavila, da vitko proizvodnjo pravzaprav določajo trije osnovni elementi (Koskela, 2004, str. 7):

- Tok: Proizvodnja mora potekati v obliki zveznega toka enega izdelka skozi vse proizvodne procese. Definirajo se aktivnosti, ki dodajajo vrednost proizvodu, bodisi neposredno bodisi so nujne $v$ obliki podpornih procesov. Vse druge aktivnosti, ki ne dodajajo vrednosti, se iz procesa izločajo. 
- Poteg: Vedno kupec vzame predhodni proizvod od dobavitelja predhodne faze skozi proces le na osnovi realnih potreb in zahtev. Torej kupec vzame tisto, kar želi, ko želi in kolikor želi.

- Težnja k popolnosti:Spremembe sistema se morajo odvijati kontinuirano in na vseh ravneh procesov s ciljem optimiziranja sistema. Neprestano se še naprej izločajo aktivnosti, ki ne prinašajo dodane vrednosti, iz česar izhaja, da podjetje nikoli ne more postati popolnoma vitko.

Vitka proizvodnja sicer zajema skupek tehnik in orodij, med katerimi so najbolj znana in uporabljena naslednja:

- Q-orodja: Vsaka izboljšava zahteva predhodno poznavanje procesa, kar omogočajo predvsem različne grafične tehnike, kot so diagrami poteka, Pareto diagrami, histogrami, procesni diagrami, diagrami vzroka in učinka (Novatus, b. d.).

- Poka-Yoke (otročje lahko): Bistvo je preprečevanje nenamernih napak v proizvodnih procesih (Khamesra, Deskmukh \& Nayar, 2013, str. 4). Gre za pristop, ki preprečuje, da bi sestavni deli neustrezne kakovosti vstopili v nadaljnji proces, in odstranjuje vzroke za nastanke napak.

- TPM (celovito produktivno vzdrževanje): Cilj TPM je izboljšati učinkovitost strojev in opreme z zmanjševanjem zastojev zaradi neustreznega vzdrževanja ter zagotoviti, da na proizvodih ni napak, ki bi bile povzročene na proizvodnih linijah (Čala, 2011, str. 60).

- SMED (metoda hitre menjave orodij): Med menjavo in nastavitvami orodij ne ustvarjamo nove vrednosti, zato mora biti ta čas čim krajši, ker tako zmanjšamo celotne stroške, povezane z menjavo orodij in nastavitvijo strojev (QM partner, b. d., str. 1).

- Uravnoteženost procesa: Usklajenost operacij in opravil v proizvodnem procesu vpliva na učinkovitost poslovanja, zato mora biti trajanje posameznih operacij prilagojeno tempu proizvodnje (Kavčič, 2006, str. 9). Tako se odpravijo prekomerne zaloge končnih izdelkov ter zmanjšajo medfazne zaloge.

- Proizvodne celice: Pri celični proizvodnji so proizvodne delovne enote in oprema razporejeni v zaporedju, ki podpira nemoten pretok materialov in sestavnih delov skozi proizvodni proces z minimalnimi fizičnimi premiki (transportom) ali zamudami (Inman, b. d.). Obdelovanci se premikajo skozi celotni proizvodni proces kos za kosom, z dinamiko, ki je prilagojena zahtevam oziroma potrebam kupca.

- Kanban: Je vizualni signal, ki se uporablja za zagon določene aktivnost. Bistvo je v sistemu dispečiranja in oskrbe delovnih mest z materialom in obdelovanci po načelu vlečenja (pull), ki zahteva proizvodnjo potrebnih delov le v zahtevanih količinah in ob pravem času in na pravem mestu (Radigan, b. d.).

- Kaizen: Izraz izvira iz japonskih besed kai, ki pomeni »sprememba«, in besede zen, ki pomeni »na boljše«. Osnova filozofije Kaizen je izraba 
znanja, izkušenj in veščin vseh zaposlenih v podjetju in sloni na zamisli, da lahko vsakdo prispeva k boljšemu delovnemu okolju (Čufar, 2010, str. 591). Ta proces stalnih izboljšav je dolgoročen in kontinuiran, zajema vse ravni v organizaciji in omogoča odzive na spremembe okolja.

Lahko torej strnemo, da vitko organizacijo najpomembneje določata njena strateška usmeritev ter proces nenehnega izboljševanja s ciljem odstranjevanja vseh elementov ali aktivnosti, ki ne ustvarjajo dodane vrednosti. Z vidika končnega kupca, ki uporablja proizvod ali storitev, je v dodani vrednosti zajet vsak ukrep ali postopek, ki ga je kupec pripravljen plačati.

\section{Vitka organizacija v javnem sektorju v tujini}

Država kot temeljna in osrednja socialna tvorba za delovanje potrebuje institucije oziroma službe, ki delujejo na posameznih področjih družbenega življenja. Sistem javne uprave in, širše, javnega sektorja torej opravlja naloge javnega pomena in zagotavlja javne dobrine, ki so za obstoj družbe nujno potrebne, do njih pa ni mogoče priti prosto, po načelu trga, ampak le preko institucij države ali subjektov, ki jim je država podelila pristojnosti za izvajanje raznih javnih storitev.

S ciljem povečati učinkovitost delovanja in hkrati zmanjšati stroške delovanja javnega sektorja so izvršne oblasti predvsem v Veliki Britaniji, Združenih državah Amerike in na Švedskem spodbujale subjekte javnega sektorja, da v svoje delovanje uvedejo pristope vitkosti. Posledično je uporaba vitke organizacije v javnem sektorju že bila predmet številnih raziskav v zadnjih 15 letih. Med temeljnimi spoznanji o uporabi vitke organizacije v javnem sektorju lahko tako omenimo predvsem naslednje.

Beck in Hjelle (2009) ugotavljata, da vitkost ustvarja dodano vrednosti vjavnem sektorju. Rezultate lahko najdemo tako na strani večje učinkovitosti kot tudi izboljšanja delovne klime. Kot glavno oviro uvedbi izpostavljata pomanjkanje znanja o načelih in metodah vitkosti pri zaposlenih v javnem sektorju, zato sta potrebna tako izobraževanje sodelavcev kot tudi vzporedna pomoč izkušenih zunanjih svetovalcev.

Radnor (2005) navaja, da je učinkovita uvedba in uporaba vitkosti v javnem sektorju odvisna tako od organizacijskih dejavnikov kot tudi od kulture organizacije. Osredotočanje samo na reduciranje stroškov, zmanjševanje napak ter izboljšanje zanesljivosti oskrbe ne more ustrezno preoblikovati organizacije.

Perger (2002) poroča, da vitko razmišljanje išče poti za odstranjevanje nepotrebnih stvari iz proizvodnega procesa, ki se razteza od oblikovanja do prodaje kupcu prilagojenega proizvoda. 
Hines (2012) navaja, da bo vitkost v organizaciji mogoče vzpostaviti le, če bo velik odstotek sodelavcev ne samo mislil, da vitkost deluje, pač pa videl koristi od tega tudi zase.

Krings, Levine in Wall (2006) ugotavljajo, da so sodobni menedžerji prevzeli koncept vitkosti in naredili pomemben korak v procesih državne in lokalne uprave z jasnim identificiranjem aktivnosti, ki morajo biti odpravljene, poenostavljene ali izboljšane.

Di Pietro, Mugion in Renzi (2013) trdijo, da izvajanje programa Kaizen v okviru metod vitkosti zahteva holističen oziroma celovit pristop. Nujna je integracija notranjih in zunanjih vidikov javnih storitev, kajti le ta lahko vodi kzmanjševanju porabe ter povečanju zadovoljstva državljanov.

Miranda (2012) izpostavlja, da uporaba metod vitkosti v praksi pomeni prednost, ker se problemi praviloma rešujejo v operativi brez pomembnejšega sodelovanja vrhnjega menedžmenta. So pa menedžerji vključeni $v$ faze predloga rešitve in odločanja o rešitvi.

Za namen raziskave smo preučili določene primere uvedbe vitke organizacije v javni sektor v Združenih državah Amerike, Veliki Britaniji ter na Švedskem.

\subsection{Uporaba vitke organizacije v javnem sektorju v ZDA}

V Združenih državah Amerike so vitko organizacijo že uvedli v posamezne subjekte javnega sektorja, in sicer tako na ravni federacije - Agencija za okolje (EPA) ter Ameriška vojska (US Army) -, kakor tudi v posameznih zveznih državah - Kolorado, Connecticut, lowa, Maryland, Maine, Minnesota, Michigan in New Hampshire. Koncepte vitkosti pa so vpeljali tudi v upravah posameznih mestnih oblasti - Cape Coral (Florida), Grand Rapids (Michingan), Jacksonville (Florida), Country of Ventura (Kalifornija) ter Brown Country (Wisconsin) (Lindquist \& Taylor, 2013, str. 1). V nadaljevanju bomo navedli nekaj primerov, kjer so učinki uvedbe vitkosti ustrezno konkretizirani.

\section{Agencija za zaščito okolja - angl. Environmental Protection Agency (EPA)}

Agencija za zaščito okolja ima poleg glavnega štaba teritorialno razdeljenost na deset regionalnih uradov, vsak od njih pokriva določene zvezne države. Skupno zaposluje okrog 15.500 uslužbencev, letni proračun Agencije je približno osem milijard dolarjev (EPA, b. d., str. 1).

S sistematično uporabo metod vitkosti so uspeli zaposleni tako na sedežu EPA kot tudi na regionalnih uradih skrajšati trajanje procesov določenih skupin storitev. Tako so na primer v zvezni državi lowa, na Oddelku za naravne resurse, uspeli zmanjšati število odločitvenih korakov pri potrjevanju dovoljenj za podzemna skladišča za $80 \%$, hkrati pa število procesnih opravil reducirati s prejšnjih 43 na sedanjih 26. To je v končni fazi pomenilo skrajšanje procesa odločanja z 38 na tri mesece po novem načinu dela (EPA, 2009, str. 8). 
V Agenciji za kontrolo onesnaževanja v Minnesoti so do leta 2003, pred uvedbo metod in tehnik vitkosti, izdali manj kot $10 \%$ soglasij za izpuste odpadnih vod znotraj predvidenega roka, ki je bil 180 dni od prejetja zahtevka. Za cilj so si zadali, da z ustreznim usposabljanjem zaposlenih in prenovo procesov do leta 2005 dosežejo, da bo 90 \% dovoljenj izdanih v 180 dneh. Dejanski dosežek je bil 75 \% izdanih dovoljenj v predvidenem roku v letu 2006, hkrati se je število popravkov dokumentacije zmanjšalo z 20 na 8,5 \% (EPA, 2003, str. 1).

\section{Ameriška vojska - angl. US Army}

Med letoma 2004 in 2006 je bil v posamezne rodove ameriške vojske uveden program Lean Six Sigma Excellence Awards, znan kot LEAP. Od takrat je bilo usposobljenih več kot 11.000 strokovnjakov za procese vitkosti in kakovosti, ki so iskali in nato odpravljali neučinkovitosti, zmanjševali odstopanja od želenega stanja ter povečevali splošno kakovost storitev in produktov. Ti strokovnjaki so sedaj razporejeni praktično v vseh enotah vojske (Schmidt, b. d., str. 1). Vsako leto je bilo zagnanih okrog 2000 posameznih projektov, prihranek zaradi izboljšav procesov pa je ocenjen na približno pet milijard USD.

\section{Oddelek za kakovost okolja zvezne države Michigan - angl. Michigan Department of Environmental Quality}

Vodilni v industrijskih podjetjih v zvezni državi Michigan so menili, da je izdajanje okoljevarstvenih dovoljenj s strani pristojnega državnega urada okorno, počasno in neodzivno (EPA, 2003, str. 1). Oddelek za kakovost okolja na državni ravni je zato pričel iskati možnosti za izboljšanje procesa. Vodstvo oddelka je pripravilo srečanje z menedžerji industrijskih podjetij (General Motors, DaimlerChrysler itd.), ki so ga vodili strokovnjaki za vitkost iz korporacije General Motors. Skupaj so pripravili diagrame procesa, da bi bolje razumeli potrebne aktivnosti in identificirali ozka grla.

Prenovljen proces obravnave vlog se je izkazal za enostavnejšega ter ažurnejšega, odpravil je čakanje ter ponovne postopke. Temeljni rezultati prvega leta uvajanja vitke organizacije so bili naslednji (EPA, 2003, str. 2):

- postopek za reševanje vloge se je za najpomembnejša dovoljenja skrajšal s 422 na 98 dni,

- za manj pomembne vrste dovoljenj se je postopek skrajšal s 143 na 50 dni,

- za $16 \%$ se je izboljšala popolnost vlog prosilcev,

- izboljšani so bili odnosi med vsemi deležniki v procesu ter

- opazno se je povečala delovna motiviranost zaposlenih na oddelku.

\section{Minnesota}

Zvezna država Minnesota je vzpostavila Komisijo za inovacije storitev - angl. Commission on Service Innovation (CSI), ki je nato priporočila zagon programov vitkosti na vseh ravneh te države (MWCC, b. d.). V program vitkosti je bilo $v$ treh letih vključenih 17 državnih agencij, ki so preoblikovale skupno več 
kot 170 različnih poslovnih procesov. Agencije so realizirale cilje izboljšanja produktivnosti, saj se je v povprečju čas trajanja storitev od začetka do konca postopka skrajšal za dve tretjini, medtem ko se je efektivni čas $v$ smislu delovnih ur za postopek zmanjšal za 45 \% (MWCC, b. d.).

Na podlagi doseženih rezultatov, predstavljenih v navedenih raziskavah in poročilih ustreznih organov, lahko ugotovimo, da so orodja in tehnike vitke proizvodnje v organizacijah javnega sektorja ZDA bistveno izboljšale delovanje teh organizacij. Pomembna so predvsem hitrejše izvajanje procesov, znižanje stroškov ter povečanje kakovosti dela, kar izkazujejo kazalniki notranje učinkovitosti (zmanjšanje potrebnih aktivnosti v procesu, skrajšanje skupnega časa od sprejema vloge do izdaje dovoljenja ipd.). Pri vseh predstavljenih primerih tudi ni bilo izpostavljenih oziroma zabeleženih negativnih rezultatov uporabe vitke organizacije.

\subsection{Uporaba vitke organizacije v javnem sektorju Velike Britanije}

V Veliki Britaniji se je pod premierko Margaret Thatcher pričelo obsežno prestrukturiranje javnega sektorja. Temeljilo je na načelu, da so tržni mehanizmi najučinkovitejši način za alokacijo resursov znotraj javnega sektorja, in tako se je pričel prenos določenih izbranih javnih storitev na zasebna podjetja (Andrews, 2013, str. 8). Za institucije javnega sektorja, ki so še naprej zagotavljale določene vrste javnih storitev, pa se je pričela uveljavljati paradigma novega javnega menedžmenta (NPM).

Še posebej intenzivno se orodja in metode vitkosti uporabljajo v državni upravi Velike Britanije po letu 2011, ko je Urad kabineta objavil strategijo nenehnih izboljšav v vseh centralnih vladnih službah, ki zahteva med drugim tudi njihovo uvedbo ter vgradnjo načela nenehnih izboljšav v procese poslovanja.

\section{Zdravstvo}

Javne zdravstvene ustanove so zaradi deleža BDP, ki se namenja njihovemu delovanju, eden od ključnih subjektov, kjer je v masi mogoče doseči precejšnje prihranke. Tako so se metode vitkosti pričele v sisteme javnega zdravstva uvajati po letu 2005, in to predvsem v bolnišnice, da bi odpravili podvajanje procesov in nepotrebnih procedur (Fillingham, 2007, str. 3). Ena od prvih bolnišnic, ki je z metodami in tehnikami vitke organizacije skušala izboljšati svoje procese poslovanja, je Royal Bolton Hospital v Greater Manchestru. Razvili so sistematičen in celovit pristop k organizacijski kulturi, ki vodi k izboljšavam in varnosti. Rezultati uporabe vitke organizacije so omogočili pomembno izboljšanje učinkovitosti in kakovosti delovanja na različnih področjih. Tako se je npr. (BCS, 2009, str. 2):

- čas bivanja v bolnišnici se je skrajšal za 33 \%,

- povečala učinkovitost dela na patologiji, kjer so bili izvidi narejeni tri- do desetkrat hitreje, hkrati so površino prostorov patologije zmanjšali za $40 \%$, 
- izboljšala se je uspešnost delovanja, saj je bilo ustvarjenih 3,1 milijona funtov prihrankov pri stroških na letni ravni.

\section{Davčna in carinska uprava}

Davčna in carinska uprava Velike Britanije (HM Revenue and Customs ali kratko HRMC) je eden od najbolj preučevanih ter tudi najbolj kontroverznih primerov uvajanja vitke organizacije v javni sektor.

Gre za ogromen organ državne uprave, ki ima preko 70.000 zaposlenih na več kot 100 mestih znotraj države (Bourton Group, 2009, str. 2). Vanj so program vitkosti pričeli uvajati leta 2006 s ključnim ciljem izboljšati učinkovitost in storitve za uporabnika za 30 \% po kazalnikih produktivnosti ter številu napak. Najpomembnejši cilji so bili naslednji: izboljšati delež pobranih dajatev, zmanjšati stroške delovanja ter povečati zadovoljstvo uporabnikov.

Za merjenje in vrednotenje učinkovitosti so uporabili niz kazalnikov, in sicer: število primerov/zahtevkov, obdelanih v enem dnevu (produktivnost), število primerov/zahtevkov, obdelanih pravilno, (kakovost) ter čas, potreben za obdelavo primera/zahtevka (trajanje postopka). Temeljni rezultati izvajanja projekta so bili naslednji: za polovico se je skrajšal odzivni čas, čas reševanja pritožb se je skrajšal s 15 na 6 mesecev ter zahtevki za vračilo plačanih davščin so bili obdelani v 15 delovnih dneh namesto v prejšnjih 25 (Bourton Group, 2009, str. 4).

Spremenjeni procesi poslovanja pa so prinesli tudi pozitivne učinke, ki jih je težko neposredno izraziti s kazalniki, so pa zelo pomembni za samo poslanstvo in temeljne cilje HMRC. Pomembno je postalo timsko delo in zaposleni, ki so se domislili določenih rešitev ter jih vpeljali v svoje urade, so te pozitivne izkušnje oziroma rešitve prenesli tudi do sodelavcev v drugih uradih (Bourton Group, 2009, str. 2).

Po drugi strani pa posamezne objavljene raziskave omenjajo tudi negativne učinke uvedbe vitke organizacije v Davčno in carinsko upravo Velike Britanije. Tako npr. Emiliani (2011, str. 1) ugotavlja, da so bile javne storitve žal upravljane z degenerirano ter disfunkcionalno obliko nove prakse upravljanja, saj nista bili upoštevani dve temeljni zahtevi vitke organizacije - kontinuirane izboljšave in spoštovanje ljudi (zaposlenih, strank, dobaviteljev in drugih deležnikov).

Negativne učinke omenja tudi profesor John Seddon v poročilu, pripravljenem za Komisijo za zakladništvo spodnjega doma britanskega parlamenta, kjer navaja, da je neuspeh Davčne in carinske uprave Velike Britanije lekcija, kako se ne smejo voditi reforme javnega sektorja. V svojem poročilu izpostavlja naslednje probleme: (a) sorazmerno velikemu deležu davčnih zavezancev je bila davčna obveznost odmerjena nepravilno, (b) precej se je povečalo število transakcij ki so povezane z reševanjem davčnih zadev strank zaradi nepravilnih obračunov ter (c) upadla je morala zaposlenih, povečale pa so se odsotnosti ter bolniški staleži (Seddon, 2011, str. 2). 
Hkrati je prišlo do zanimivega neželenega učinka standardizacije, ko se je vodstvo preveč posvečalo standardizaciji dela in tako vzpostavilo sistem, ki preprečuje absorbiranje različnosti in variacije potreb strank. Tako se je na koncu celo povečal obseg transakcij, s tem pa so narasli tudi skupni stroški.

Da je realni učinek uvedbe metod vitke organizacije v HMRC predvsem zanikanje dosedanjih humanističnih konceptov obogatitve dela in vračanje $\mathrm{k}$ že zdavnaj preseženim menedžerskim tehnikam z začetka 20. stoletja, ugotavlja Danford (b. d., str. 25) v svoji raziskavi.

\subsection{Uporaba vitke organizacije v javnem sektorju na Švedskem}

\section{Agencija za migracije - šved. Migrationsverket}

Agencija za migracije je eden izmed organov javnega sektorja na Švedskem in je pristojna za izvajanje politike migracij. Gre za agencijo (prej urad), ki je med prvimi pričela uvajati orodja in tehnike vitke organizacije v svoje procese poslovanja (Crawford, 2012, str. 4). Leta 2007 je namreč švedska vlada zaradi dolgih zamud pri odobravanju prošenj za azil, na Migracijski urad naslovila zahtevo, naj najdejo ustrezne načine za tekočo obravnavo prispelih vlog (Crawford, 2012, str. 18). Ker so predolgi postopki za obravnavo prošenj za azil imeli negativne učinke tako za državni proračun (prosilec, dokler je v postopku za odobritev azila, stane državo okrog 100.000 SEK letno), prav tako pa so negativnosti še kako čutili tudi prosilci, so leta 2008 pričeli s projektom za skrajšanje reševanja prošenj za azil, imenovan "Shorter Waiting". Glavni začetni izziv je bil, kako zasnovati proces, v katerem bodo najstarejše vloge za azil obravnavane prednostno oziroma bo postopek končan najpozneje v šestih mesecih.

Pred začetkom projekta uvajanja vitke organizacije je bil povprečni čas trajanja postopka za odobritev azila 267 dni, po dveh letih pa se je povprečni potrebni čas skrajšal na 111 dni (Crawford, 2012, str. 21). Zaradi teh uspehov se je uporaba tehnik in orodij vitkosti prenesla z delovnega področja reševanja vlog azilantov na celotno področje dela, ki je v pristojnosti Migracijskega urada.

Glavna sprememba po uvedbi vitke organizacije v proces delovanja je, da prej ni bilo definirane odgovornosti za reševanje vsakega posameznega primera med zaporednimi delovnimi fazami, sedaj pa je povsem jasno strukturirano, kdo mora izvesti naslednjo fazo v procesu in v kakšnem roku.

Čeprav so naloge Agencije za migracije ostale v pretežni meri nespremenjene, pa se je razporejanje nalog ter spremljanje merljivih ciljev bistveno spremenilo zaradi standardizacije metod dela. Ključen je bil novi sistem za naročanje strank, ko tajnica poda termin prosilcu za obisk urada, hkrati pa isti termin vnese tudi v delovni koledar uradnika. To je hkrati tudi glavni vzrok nesoglasja med vodstvom urada na eni strani ter med uradniki na drugi strani, saj nekateri od njih trdijo, da na ta način izgubljajo nadzor nad razporejanjem delovnih opravil. Menedžerji oziroma vodje organizacijskih enot pa hkrati zagotavljajo, 
da je standardizacija delovnih nalog, še posebej glede časovnih normativov, nujna, če hočejo koordinirati delovne aktivnosti osebja oziroma uradnikov (Crawford, 2012, str. 23).

Verjetno je ravno takšen način razporejanja delovnih nalog razlog, da se je zadovoljstvo zaposlenih od leta 2009 stalno zmanjševalo. Vodstvo Migracijskega urada meni, da je razlog za to povečanje obsega dela, intenziven razvoj ter zmanjševanje proračunskih sredstev. Zanimivo je, da je za 14 \% padel tudi indeks zadovoljstva strank, pri čemer vodstvo kot razlog za to ocenjuje, da prosilci menijo, da niso ustrezno obveščani o statusu reševanja svoje vloge (Crawford, 2012, str. 23).

Gotovo normiranje porabe časa za izvedbo posameznih delovnih nalog zahteva kompromis v odnosu do kakovosti storitve in tudi v odnosu do samih prosilcev. Kakovost delovanja je pretežno izražena z merljivimi kazalniki, kot so delež zadev, ki je vrnjen s sodišča v ponovno odločanje na prvo stopnjo. Vzrok za vrnjene zadeve je lahko tudi pomanjkanje časa za ugotovitev dejanskega stanja, ker je čas za ugotovitev dejanskega stanja normiran (pre)kratko.

\subsection{Značilnosti uvedbe vitke organizacije v javnem sektorju v tujini}

Pri uvedbi vitke organizacije v javni sektor oz. še posebej v organe javne uprave je vsekakor treba omeniti tri posebnosti - tj. načelo enakosti, pomanjkanje konkurence ter kontraproduktivne spodbude, s katerimi se zasebni sektor ne sooča (Audier, Sanders \& Winslade, 2010, str. 2):

Načelo enakosti - V javni upravi velja za večino javnih storitev temeljno načelo, da mora biti vsaka stranka obravnavana enako, da se preprečijo pristranskost, diskriminacija ali samovoljno izvajanje pooblastil. Vendar pa takšna pravila hkrati lahko povzročijo, da je državni aparat bolj neprilagodljiv, počasen v odločanju, zmanjšana pa je tudi njegova zmožnost za spodbujanje inovativnih pristopov, ki bi bili prilagojeni za različne potrebe državljanov.

Pomanjkanje konkurence - Samo majhen delež organizacij javne uprave deluje v konkurenčnem prostoru, večina pa je zaradi stvarne ali krajevne pristojnosti edini ponudnik določenih vrst storitev, zato uporabnik tako nima možnosti proste izbire. Ker ni konkurence, tudi ni z njo povezanih dejavnikov, ki sicer pospešujejo inovacije.

Kontraproduktivne spodbude - Menedžerji v javnem sektorju pogosto niso nagrajeni za izboljšanje učinkovitosti oziroma so morda celo deležni negativnih učinkov zaradi takih izboljšav, če npr. prihranki privedejo do zmanjšanja proračunov organov državne uprave, namesto da bi bili namenjeni izboljšanju kakovosti storitev. 
Radnor in Johnston (2013, str. 19) pa ugotavljata, da je uvajanje vitkosti v ustanove javne uprave bistveno bolj kompleksno kot v zasebna podjetja, saj ne moremo vedno natančno določiti kupca.

Tudi Drotz (2014, str. 19) meni, da je v javnem sektorju pojem kupca težko definirati, in to tako pomensko kot tudi konceptualno. Vsekakor pa je treba kot kupce upoštevati tako državljane kot tudi stranke oziroma odjemalce storitev. Državljani nastopajo kot kolektivna družba, ki skozi politični in družbeni ustroj opredeljuje temeljne cilje organizacij javnega sektorja in izraža preference glede ponujenih storitev. Stranke pa so tisti odjemalci, ki v neposredni interakciji z institucijami javnega sektorja storitev od njih prejmejo neposredno.

Ustvarjanje toka vrednosti je eno od najpogosteje uporabljanih orodij vitkosti, saj organizacija s tem lahko zmanjša izgube, izboljša organizacijsko strukturo ter do določene mere poenoti delovne postopke. Je pa vitkost lažje uporabiti v podpornih oziroma back-office procesih organizacije, saj so tukaj procesi bolj predvidljivi in ponovljivi kot pri osnovnih oziroma front-office procesih, kjer je stik s stranko neposreden in je tudi zaznavanje ravni kakovosti storitve drugačno (Drotz, 2014, str. 21).

\section{Možnost uvedbe vitke organizacije v javni sektor Republike Slovenije}

Vitka organizacija je le eno izmed upravljavskih orodij za izboljšanje procesov delovanja, doseganja standardov kakovosti ter doseganje odličnosti organizacije.ZaSlovenijo velja, da sicernekateriavtorji (glejnpr.Dimovski, 2003; Gider, 2007; Zeni, 2014) poudarjajo pomen vitke organizacije za izboljšanje učinkovitosti delovanja javnega sektorja, vendar za zdaj ni evidentiran oziroma objavljen noben primer, da bi se vitka organizacija dejansko uvedla v delovanje katerega koli subjekta v javnem sektorju v Republiki Sloveniji. Pri nekaterih subjektih so sicer v uporabi določene delne metode in tehnike vitke organizacije, kot je Kaizen kot metoda stalnih izboljšav, vendar popolne uvedbe z vzpostavitvijo toka vrednosti ter izločanjem potrat, ki bi imela tudi merljive učinke izboljšav v učinkovitosti delovanja, nismo zasledili.

Če se bo kdaj začelo uvajanje v subjekte javnega sektorja Republike Slovenije, bo predvsem treba izhajati iz dejanskih potreb strank oziroma odjemalcev storitev, za katere opazen prispevek ne more biti zgolj notranja učinkovitost konkretnega subjekta.

Vodstvo izbraneskupine subjektovter ključnisodelavci, ki bi delovali na pilotskih projektih, bi morali najprej z intenzivnimi usposabljanji in realnimi študijami primerov pridobiti potrebna dodatna znanja. Uvedbo vitke organizacije bi sicer teoretično lahko izvedli tudi s projektnim delom posameznega subjekta, vendar bi bil takšen pristop nepopoln in ne bi omogočal potrebnih sinergijskih učinkov. To bi se odražalo tako v sorazmerno visokih stroških na posameznega 
udeleženca usposabljanj kot v vprašanju, ali smo dejansko sploh pridobili vsa potrebna znanja. Druga slabost je možnost motiviranja zaposlenih v konkretnem subjektu, da intenzivno in zavzeto pristopijo k uvajanju vitke organizacije, saj se bodo pri večini sodelavcev zagotovo pojavljala vprašanja in dvomi, kaj pravzaprav predstojnik dotičnega subjekta sploh želi in zakaj, če pa drugi istovrstni ali primerljivi subjekti ne uporabljajo te rešitve.

Odločiti bi se bilo treba tudi za način uvedbe, pri čemer se izpostavljajo vsaj naslednje možnosti:

- ali vitko organizacijo pilotsko uvesti v nekaj izbranih subjektih ali pa projekt pričeti pri vseh istovrstnih subjektih hkrati,

- uvajati vitko organizacijo globalno na način popolne uvedbe, hkrati od zgoraj navzdol in od spodaj navzgor v obsegu celotnega subjekta, ali pa uporabiti delni pristop pri nekaj procesih, da se že kratkoročno pokažejo pozitivni učinki,

- ali najprej pričeti uvajanje v podporne procese, kjer dela in naloge niso neposredno povezane s strankami (finančne in kadrovske zadeve, informatika, nabava, arhiviranje ipd.), ali pa vitko organizacijo uvajati v ključnih procesih in postopkih, kjer bo prišlo tudi do vidnega učinka izboljšav na same odjemalce storitev (skrajšanje časa trajanja storitev in postopkov).

Pri sicer neobhodni standardizaciji procesov bo nujen tudi pragmatičen način razmišljanja, in sicer bo treba poenotiti postopke le do mere, ki ne preprečuje absorbiranja različnosti in variacij potreb strank. Preveč togo predpisan postopek za izvajanje neke upravne storitve bi čas reševanja samo podaljšal.

Vsekakor je vitko organizacijo mogoče uvesti tudi v subjekte javnega sektorja v Republiki Sloveniji, vendar je prvi pogoj iniciativa političnega vodstva države, ki bi moralo izbrati način uvedbe, ki bo v razumnem času pokazal merljive in konkretne pozitivne učinke ter tako prispeval k izgradnji pozitivne podobe javnega sektorja kot učinkovitega servisa za državljane.

\section{Razprava}

Vitka organizacija v procesih delovanja subjektov javnega sektorja ima pretežno pozitivne učinke, predvsem glede dviga učinkovitosti delovanja, to je višje produktivnosti in nižjih stroškov. Predvsem se zaznava skrajšanje časa, ki je potreben za izvedbo določene storitve, nato reduciranje potrebnih aktivnosti v procesu ter vzporedno še prihranek sredstev zaradi zmanjšanja potrebnega števila zaposlenih kot strošek dela. Z vidika tako imenovanih »mehkih elementov« pa je poudarjeno zmanjšanje stresa pri zaposlenih, ker postopki tečejo bolj tekoče in z manj ovirami.

Se je pa treba zavedati tudi nekaterih omejitev, med drugim tudi dejstva, da je v zasebnem sektorju precej lažje definirati cilje kakovosti poslovanja 
kot $v$ javnem sektorju, saj je v slednjem raven neke storitve praviloma opredeljena z zakonsko regulativo in to bodisi neposredno ali pa preko kvote resursov, ki so v danem trenutku na voljo - število kadrov, finančna sredstva ipd. Torej država oziroma vladajoča politika že v splošnem določi, kakšna bo raven neke konkretne storitve do uporabnika (npr. normativi v vrtcih in šolah, čakalna doba za operacije v bolnišnicah ipd.).

Osnovno načelo vitke proizvodnje, da so potrebne aktivnosti le tiste, ki dodajajo vrednost in jih je kupec tudi pripravljen plačati, težje uporabimo v javnem sektorju, saj uporabnik neposredno ne plača storitve (razen morda kakšne upravne takse ipd.). Zato je težko povečati vrednost z dodajanjem določenih atributov neki storitvi.

Merjenje tehničnih karakteristik kakovosti, kot je povprečni čas reševanja vlog in podobno, je gotovo lahko zelo uporabno v javnem sektorju, vendar je kakovost storitve z vidika stranke vseeno treba obravnavati v vsej njeni kompleksnosti in pridobiti povratne informacije o potrebah kupcev in njihovih pričakovanjih glede javnih storitev, da jih lahko nato uporabimo kot vhodno informacijo za izboljšave procesa. Gotovo pa v vsaki organizaciji obstajajo možnosti za uporabo metod in orodij vitkosti, da se vzpostavi učinkovitejši proces poslovanja.

\section{Zaključek}

Pritisk davkoplačevalcev za zmanjševanje stroškov delovanja javnega sektorja je stalen ter izrazit in dejstvo je, da bo javni sektor moral pospešeno iskati ustrezne načine za povečanje svoje učinkovitosti. Ni pa enostavno povsem enoznačno odgovoriti, ali je uvajanje koncepta vitkosti kot način za povečanje učinkovitosti in racionalnosti res najboljša rešitev za javni sektor. Vsekakor so se orodja in tehnike vitke proizvodnje pričele uvajati v subjekte javnega sektorja šele pred dobrimi desetimi leti, pri čemer je npr. Toyota potrebovala več kot 20 let, da je koncept vitke proizvodnje ustrezno izpopolnila (Crawford, 2012, str. 33).

Iz dosedanjih izkušenj z uvajanjem koncepta vitkosti v javni sektor v določenih državah pa lahko sklepamo, da vitka organizacija dejansko lahko pripomore k boljši učinkovitosti in racionalnosti delovanja subjektov javnega sektorja, vendar programov vitkosti nikakor ne smemo usmeriti niti razumeti kot preprosto rezanje stroškov, pač pa zgolj kot pristop, s katerim lahko težavno situacijo spremenimo v organizacijsko priložnost za osmislitev načina, kako naj bodo javne storitve nudene v prihodnosti. Skratka, gre za iskanje poti, kako javni sektor narediti čim učinkovitejši in ga približati uporabnikom s ciljem ustvarjanja ustreznega družbeno-ekonomskega okolja za razvoj družbe. 
Emil Trontelj

Mag. Emil Trontelj je načelnik Upravne enote Slovenska Bistrica. Magistriral je na Ekonomsko-poslovni fakulteti Maribor, smer management in organizacija, na temo vitke organizacije v upravni enoti. Že več let se ukvarja z optimizacijo procesov poslovanja ter s preučevanjem možnosti uvedbe metod in tehnik vitke proizvodnje, sprva v poslovanje gospodarskih družb, sedaj pa v poslovanje organov državne uprave. Prispevek temelji na avtorjevem magistrskem delu z naslovom Vitka organizacija $v$ upravni enoti. 


\section{Literatura in viri}

Andrews, R., Downe, J., \& Guarneros-Meza, V. (2013). Public sector reform in the UK: Views and experiences from senior executives. Pridobljeno 2. 7. 2015, s http://www.cocops.eu/wp-content/uploads/2013/06/UK_WP3-CountryReport.pdf

Audier, A., Sanders, U., \& Winslade, P. (2010). More than lean: Raising the quality of public services. Pridobljeno 3. 9. 2015, s https://www.bcg.com/documents/ file66326.pdf

BCS. (2009). A Leaner care system for Bolton. Pridobljeno 12. 8. 2015, s http:// www.bcs.org/content/conWebDoc/27106

Beck, A. M., \& Hjelle, J. T. (2009). Lean in the Danish public sector (M.Sc. Business Performance Management Thesis). Aarhus University. Pridobljeno 18. 9. 2015, s http:// benoit.grunewald.fr/.../Lean-in-the-Danish-Public-Sector

Bhatia, N. \& Drew, J. (2006). Applying lean production to the public sector. Pridobljeno 10. 3. 2014, s http://www.mckinsey.com/industries/public-sector/ our-insights/applying-lean-production-to-the-public-sector

Bourton Group (2009). Lean puts the customer at the heart of HMRC. Pridobljeno 22. 8. 2015, s http://www.bourton.co.uk/PDF/finacialservices/HMRC.pdf

Crawford, J. (2012). Lean production in the public service sector (Master thesis). Uppsala University. Pridobljeno 12. 8. 2015, s http://www.diva-portal.org/ smash/get/diva2:540047/FULLTEXT02

Čala, I. (2011). Održavanje. Pridobljeno 2. 7. 2015, s https://www.fsb.unizg.hr/ atlantis/upload/newsboard/20_12_2011_13552_1_Uvod_u_odrzavanje_ opreme.pdf

Čufar, M. (2010). Kaizen-koncept stalnih izboljšav. Zbornik 7. festivala raziskovanja ekonomije in managementa (str. 591-597). Pridobljeno 12. 8. 2015, s http:// www.fm-kp.si/zalozba/ISBN/978-961-266-122-9/prispevki/068.pdf

Danford, A. (b. d.). Lean management, the restructuring of work in the public sector and implications for employee well-being. Pridobljeno 9. 8. 2015, s http:// www2.uwe.ac.uk/.../AD_CESR_Review_Jan_12.pdf

Deskmukh, A., Khamesra, A., \& Nayar, A. (2013). Poka-Yoke (Mistake proofing) [PowerPoint]. Pridobljeno 19. 8. 2015, s https://www.slideshare.net/ animeshkhamesra/poka-yoke-mistake-proofing-26424292

Dimovski, V. (2003). Sodobni management. Ljubljana: EF Ljubljana.

Di Pietro, L., Mugion, R. G., \& Renzi, M. F. (2013). An integrated approach between Lean and customer feedback tools: An empirical study in the public sector. Total Quality Management \& Business Excellence, 24(7-8), 899-917. doi: 10.1080/14783363.2013.791106

Drotz, E. (2014). Lean in the public sector possibilities and limitations (Licentiate dissertation). Linköping University.

Emiliani, B. (2011). Lean management failure at HMRC. Pridobljeno 7. 8. 2015, s http://www.bobemiliani.com/goodies/emiliani_hmrc.pdf

Environmental Protection Agency - EPA. (2003). EPA Wastewater Permitting Process Six Sigma Project Case Study. Pridobljeno 12. 8. 2015, s http://www2. epa.gov/sites/production/files/2015-08/documents/mn-casestudy.pdf

Environmental Protection Agency - EPA. (2009). Lean in government starter kit (ver. 2.0). Pridobljeno 17. 5. 2015, s https://dom.iowa.gov/sites/default/files/ documents/2015/08/lean_govt_starter_kit-v2_7-09.pdf 
Environmental Protection Agency - EPA. (b. d.). EPA's budget and spending. Pridobljeno 11. 8. 2015, s http://www2.epa.gov/planandbudget/budget

Fillingham, D. (2007). Can lean save lives? Leadership in Health Services, 20(4), 231-241. doi: 10.1108/17511870710829346

Gider, F. (2007). Vitka proizvodnja - Lean manufacturing. Ljubljana: Zavod za tehnično izobraževanje.

Hines, P. (2012). Applying lean in the public sector. SA Partners. Pridobljeno 14. 5. 2014, s http://sapartners.com/applying-lean-in-the-public-sector/

Inman, R. A. (b. d.). Cellular manufacturing. Pridobljeno z 05. 8. 2015, s http:// www.referenceforbusiness.com/management/Bun-Comp/CellularManufacturing.html

Johnston, R., \& Radnor, Z. (2013). Lean in UK Government: internal efficiency or customer service. Production Planning and Control ,24(10-11), 903915. Pridobljeno 7. 6. 2015, s https://dspace.lboro.ac.uk/dspace-jspui/ bitstream/2134/15859/1/PPC_Paper_ZR_BJ_final\%203.pdf

Kavčič, K. (2006). Management oskrbnih verig in model taktnega časa. Koper: Fakulteta za management Koper. Pridobljeno 2. 8. 2015, s http://www.fm-kp. si/zalozba/ISBN/978-961-266-046-8.pdf

Koskela, L. (2004). Moving on - beyond lean thinking. Lean Construction Journal, 1(1) , 24-37. Pridobljeno 5. 7. 2015, s http://usir.salford.ac.uk/9385/1/2004_ Moving_On_Beyond_Lean_Thinking.pdf

Krings, D., Levine, D., \& Wall, T. (2006). The use of "lean" in local government. ICMA Public management Magazine, 88(8). Pridobljeno 18. 6. 2014, s http:// www.grand-rapids.mi.us/city-manager/Documents/8142_Sept\%202006\%20 -\%20ICMA\%20Article\%20on\%20Lean\%20in\%20Local\%20Govt.pdf

Liker, J. K. (2004). The Toyota way. New York: McGraw-Hill.

Lindquist, K. (2013). Synthesis of lean information and practice in government. Pridobljeno 5. 7. 2015, s http://lean.nh.gov/documents/ LeanPracticesInGovSynthesisUpdate112013.pdf

Maleyeff, J., \& Campus, H. (2007). Improving service delivery in government with Lean Six Sigma. Pridobljeno 29. 7. 2014, s http://www.doh.wa.gov/Portals/1/ Documents/1000/PMC-ImproveServiceDeliveryLeanSixSigmaReport.pdf

Maryland World Class Consortia - MWCC. (b. d.). Lean government-Minnesota Commission calls for expanding lean deployment. Pridobljeno 5. 7. 2015, s http://www.mwcmc.org/leangovernment

Miranda, G. (2012). Using Lean Six Sigma: A case study: 2012, Lean county, USA. Pridobljeno 5. 2. 2014, s http://www.goleansixsigma.com/a-case-study-leancounty-usa/

Novatus. (b. d.). 7 Quality Tools - Making Lean Six Sigma work. Pridobljeno 12. 7. 2015, s http://www.beyondlean.com/7-quality-tools.html

Perger, S. (2002). Tudi manjša podjetja so lahko vitka. Finance.si. Pridobljeno 18. 5. 2014, s http://www.finance.si/24774/Tudi-manjša-podjetja-so-lahko-vitka

QM-Partner. (b. d.). SMED. Pridobljeno 22. 7. 2015, s http://qm-partner.com/ index.php?option=com_content\&view=article

Radigan, D. (b. d.). A brief introduction to kanban. Pridobljeno 2. 8. 2015, s https:// www.atlassian.com/agile/kanban

Radnor, Z. (2005). Evaluation of the lean approach to business. Pridobljeno 12. 5. 2014, s http://www.gov.scot/Publications/2006/06/13162106/0 
Schmidt, E. (b. d.). Lean Six Sigma is in the Army now, improving efficiency. Pridobljeno 9. 7. 2015, s https://www.isixsigma.com/industries/governmentnon-profit/lean-six-sigma-army-now-improving-efficiency/

Seddon, J. (2011). The administration and effectiveness of HMRC. Pridobljeno 18. 8. 2015, s https://www.publications.parliament.uk/pa/cm201011/cmselect/ cmtreasy/memo/hmrc/27.htm

Zeni, J. (2014). Vitalizacija - realnost ali iluzija? Delo. Pridobljeno 15. 9. 2014, s http://www.delo.si/mnenja/gostujoce-pero/vitalizacija-ndash-realnost-aliiluzija.html 
SUMMARY

\subsection{Professional article}

\section{Lean Organisation in the Public Sector}

In modern societies, the public sector has a significant impact on all areas of organised human activity and the general development of society. Changes in the environment and the increasing expectations of clients as users of public services require improved processes of the public sector subjects' operation to achieve reduced costs, the quicker implementation of services and better service quality. In some countries, executive authorities have already introduced the methods and techniques of lean production or lean organisation into the operation of public sector institutions as one of the possible systematic improvement tools.

The primary purpose of this article is to demonstrate the results of introducing lean organisation into the public sector in some countries and to point out all the specifics of this implementation. We want to obtain comprehensive answers on whether or not the methods and techniques of lean organisation are a useful approach for improving the efficiency of the public sector.

Lean organisation is a strategic policy that approaches the identification and elimination of wasteful elements from the business process in a comprehensive and systematic way. The goal of its application is to eliminate all elements or activities that do not bring added value from the customer's perspective. Therefore, its application can significantly shorten the time needed to produce a product or carry out a service.

For the purpose of research, we have studied certain examples of introducing lean organisation in the public sector in the United States of America, the United Kingdom and in Sweden. Our findings are as follows.

In the United States of America, lean organisation has already been implemented in some public sector subjects at the federal level - the United States Environmental Protection Agency and the US Army, as well as in individual states - Colorado, Connecticut, lowa, Maryland, Maine, Minnesota, Michigan and New Hampshire. Lean concepts have also been introduced in the administrations of certain city authorities - Cape Coral (Florida), Grand Rapids (Michigan), Jacksonville (Florida), the County of Ventura (California) and Brown County (Wisconsin).

With the systematic implementation of lean methods, the employees at the United States Environmental Protection Agency head office and regional offices have managed to shorten the duration of processes of certain groups of services. In the state of lowa's Department of Natural Resources, they managed to reduce the number of decision stages for issuing permits for underground storage tanks by $80 \%$ and, at the same time, reduce the number of process steps from 43 to 26 . Consequently, the decision-making timeframe dropped from 38 to 3 months. 
At the Michigan Department of Environmental Quality, they also renovated their permit application processing procedure. The procedure has become simpler and more up-to-date. It has eliminated waiting time and duplicated procedures. One year after the introduction of the new processes, the timeframe for major permits was reduced from 422 to 98 days, and the timeframe for minor permits dropped from 143 to 50 days. Relationships among all the stakeholders were improved and employees' work motivation increased.

The state of Minnesota established the Commission on Service Innovation, which then recommended the deployment of lean programmes at all levels of government. In three years, 17 state agencies entered the programme, redesigning more than 170 business processes. Agencies have realised productivity improvement goals, with the duration of services being shortened by two-thirds on average, while the effective time (labour hours per procedure) was halved.

In the United Kingdom, an extensive restructuring of the public sector was launched under Prime Minister Margaret Thatcher. It was based on the premise that market mechanisms are the most effective way to allocate resources in the public sector, so they began delegating certain public services to private companies. For the public sector institutions that were still providing public services, the New Public Management paradigm was introduced.

Lean methods began to be implemented in hospitals (e.g. the Royal Bolton Hospital, Greater Manchester) to eliminate process duplication and unnecessary procedures. They improved the efficiency and quality of operations in various areas, such as a shortened length of stay in the hospital, reduction of floor space and material costs savings.

One of the most frequently studied and controversial examples of introducing lean organisation in the public sector is the HM Revenue and Customs of Great Britain. The lean programme was implemented in order to improve efficiency and services for the customer by $30 \%$ in terms of productivity indicators and number of errors. In reality, the response time was halved, the solving of claims was shortened from 15 to 6 months, and claims for tax returns were processed in 15 working days instead of 25 . The changed processes also improved teamwork and encouraged the sharing of best practices.

On the other hand, some published research also mentions the negative effects of introducing lean organisation in HM Revenue and Customs, as they failed to take into account two fundamental requirements for lean organisation - continuous improvement and respect for people (employees, clients, suppliers and other stakeholders). The negative results included various errors in tax assessments, employee morale dropped and sick leave rates went up.

Swedish Migration Agency is one of the first public sector bodies in Sweden that started implementing the tools and techniques of lean organisation in their operational processes due to problems with long delays in processing asylum seekers' applications. Before the lean organisation project was 
introduced, the average duration of asylum approval was 267 days, while after two years the average duration was shortened to 111 days.

Based on these case studies, we can conclude that the implementation of lean organisation in the processes of public sector subjects brings positive effects, primarily in the field of efficiency. The chief benefit was a shortening of the time necessary for the implementation of certain services. The number of activities in the process was reduced and, consequently, the labour cost was reduced. In terms of the so-called "soft elements", an important benefit is the reduced stress on employees, because the procedures run more smoothly and with fewer obstacles.

In the implementation of lean organisation in the public sector, esp. in public authorities, three specific features should be mentioned that the public sector is not faced with the principle of equality, lack of competition, and counterproductive encouragement.

The principle of equality - in public administration, the basic principle for the majority of public services is that each client should be treated equally in order to prevent bias, discrimination or the arbitrary exercise of powers. However, such rules can also cause the government apparatus to be rigid, slow in decision-making and lacking innovation.

Lack of competition - Only a small number of public administration organisations experience competition. The majority of them are, due to their material or local jurisdiction, in the position of being the only provider of certain types of services.

Counterproductive encouragement - Managers in the public sector are often not rewarded for increasing efficiency or may even receive negative feedback for such improvements (e.g. savings can cause a reduction in public administration budgets, instead of being allowed to use the savings for improving the quality of their services).

The implementation of lean organisation in public administration institutions is significantly more complex than in private companies. One of the reasons is that we can't always precisely identify the customer. In any case, citizens and clients or service users need to be considered as customers.

If lean organisation is ever implemented in the public sector of the Republic of Slovenia, it will need to be based on the actual needs of the customers or service users, for which the internal efficiency of a specific subject cannot be the only observable input.

It is also necessary to be aware of certain limitations, including the fact that in the private sector, it is much easier to define quality objectives than in the public sector. In the latter, the level of a service is usually defined by law, either directly or by the quantity of resources that are available at a given moment. Lean programmes should not be understood only as the simple cutting of costs, but as an approach for determining how to shape public services in the future. 